\title{
KEBUTUHAN PROTEIN PAKAN BAGI PEMBESARAN IKAN KERAPU BEBEK, Cromileptes altivelis
}

\author{
Rachmansyah"), Petrus Rani Pong-Masak"), Asda Laining*), dan Aris George Mangawe*) \\ ABSTRAK \\ Benih ikan kerapu bebek berbobot 17,34 $\pm 2,10$ g/ekor dipelihara dalam keramba jaring \\ apung selama 60 hari dengan kepadatan $15 \mathrm{ekor} / \mathrm{m}^{3}$. Perlakuan yang dicoba adalah pakan \\ dengan kandungan protein $30 \%, 35 \%, 40 \%, 45 \%, 50 \%$, dan $55 \%$ yang diberikan secara satiasi \\ dua kali sehari. Hasil penelitian menunjukkan bahwa pakan berprotein $45 \%$ menghasilkan laju \\ pertumbuhan harian 1,35\%/hari, dan rasio konversi pakan 1,53 lebih baik dibandingkan dengan \\ perlakuan lainnya. Peningkatan kandungan protein pakan tidak berpengaruh nyata $(P>0,05)$ \\ terhadap nilai konsumsi pakan harian dan sintasan untuk semua perlakuan. Berdasarkan analisis \\ broken-line terhadap laju pertumbuhan dan rasio konversi pakan, maka dapat diduga bahwa \\ kebutuhan protein optimal pakan ikan kerapu bebek adalah $45,3 \%$
}

ABSTRACT: Study on protein requirement for grow-out of humpback grouper, Cromileptes altivelis in floating net cage. By: Rachmansyah, Petrus Rani Pong Masak, Asda Laining, and Aris George Mangawe

Juvenile of humpback grouper weighing of $17.34 \pm 2.10 \mathrm{~g} / \mathrm{pcs}$, were reared in floating net cage during 60 days with $15 \mathrm{pcs} / \mathrm{m}^{3}$ density was. Fish were fed with experimental diets containing six levels of dietary protein: $30 \%, 35 \%, 40 \%, 45 \%, 50 \%$, and $55 \%$, given twice a day by, satiation. The result showed that juvenile fed with diet containing $45 \%$ dietary protein had better growth and feed conversion ratio than those fed with diets containing 30\% - 40\% dietary protein. The increment of dietary protein levels has not significantly affect the daily feed consumption and survival rate. Based on a broken-line analysis model estimation on the daily growth rate and food conversion ratio gained, the dietary protein level that yields maximum growth of humpback grouper is $45.3 \%$

KEYWORDS: protein requirement, grow-out, humpback grouper

\section{PENDAHULUAN}

Budi daya ikan kerapu bebek (Cromileptes altivelis) dalam keramba jaring apung sangat tergantung pada pasok pakan yang diberikan karena pakan alami yang dapat diperoleh sangat terbatas. Pemenuhan pasok pakan berupa ikan rucah dapat mencapai $60 \%$ dari total biaya produksi. Selain itu, pasok pakan ikan rucah tergantung pada musim, mudah mengalami penurunan mutu, serta memerlukan fasilitas dan teknik penyimpanan yang spesifik sehingga kurang ekonomis. Karena itu, perlu pengadaan pakan buatan yang memenuhi syarat kebutuhan nutrisi ikan bagi pembesaran ikan kerapu bebek sebagai alternatif pengganti pakan ikan rucah.

Kebutuhan protein merupakan aspek penting dalam nutrisi ikan karena protein merupakan salah satu nutriea yang diperlukan oleh ikan untuk pertumbuhan (Halver, 1976). Kualitas protein bergantung pada komposisi asam aminonya terutama asam amino esensial dan derajat kecernaannya (Alava \& Lim, 1983). Jumlah kebutuhan protein pakan untuk setiap stadia biasanya berbeda, pada stadia larva dan benih membutuhkan protein pakan yang tinggi, tetapi sebaliknya rendah pada stadia pembesaran (Lovell, 1980; Boonyaratpalin, 1991; Boonyaratpalin, 1997), juga setiap spesies ikan membutuhkan protein optimal yang berbeda. Sakaras et al. (1986) melaporkan bahwa pakan dengan kandungan protein $45 \%$ dan lemak $18 \%$ memberikan pertumbuhan tertinggi pada ikan kakap putih. Protein pakan optimal bagi pembesaran ikan kakap putih dilaporkan $40 \%-45 \%$ dengan kandungan lemak 12\% (Wong \& Chou, 1989). Ikan kerapu, Epinephelus salmoides, membutuhkan protein pakan berkisar $40 \%-50 \%$ (Chua \& Teng, 1980), E. malabaricus 47,8\% (Chen \& Tsai, 1993) dan kebutuhan protein pakan optimal untuk benih ikan kerapu bebek, $C$. altivelis berbobot 5,5 $\pm 0,4$ g/ekor adalah 54,2\% (Giri et al., 1999). Pakan berkadar protein $50 \%$ dengan energi sebesar $359 \mathrm{kkal} / \mathrm{ME} / 100 \mathrm{~g}$ pakan dapat mendukung pemanfaatan pakan ikan kerapu lumpur, E. tauvina yang dipelihara dalam keramba jaring apung secara lebih efisien (Ahmad et al., 1992). Kadar tepung ikan $51 \%$ dan tepung kedelai $18 \%$ dalam pakan cocok untuk pembesaran ikan kerapu lumpur (Ahmad et al., 1992). Penelitian ini bertujuan untuk mengetahui kandungan protein opti-

\footnotetext{
Peneliti pada Balai Penelitian Perikanan Pantai, Maros
} 
mal dalam pakan yang dapat digunakan sebagai acuan dalam formulasi pakan buatan untuk pembesaran ikan kerapu bebek.

\section{BAHAN DAN METODE}

Wadah yang digunakan adalah jaring apung ukuran $1 \times 1 \times 1,2 \mathrm{~m}^{3}$ sebanyak 18 unit, diletakkan dalam satu unit rakit di perairan Teluk Labuange, Kabupaten Barru, Sulawesi Selatan. Perlakuan yang dicobakan adalah tingkatan kandungan protein dalam pakan yaitu $30 \%, 35 \%, 40 \%, 45 \%, 50 \%$, dan $55 \%$, masing-masing tiga ulangan yang disusun dalam rancangan acak lengkap. Komposisi bahan dasar pakan disajikan pada Tabel 1. Analisis proksimat bahan dasar pakan digunakan untuk menentukan kandungan nilai nutriea
Peubah biologi pertumbuhan diamati setiap bulan dengan cara menimbang seluruh ikan uji (bobot biomassa) dengan alat bantu timbangan OHAUS berketelitian $0,1 \mathrm{~g}$. Penentuan sintasan, laju pertumbuhan harian (LPH), rasio konversi pakan (RKP), rasio efisiensi protein (REP), dan konsumsi pakan harian $(\mathrm{KPH})$ dihitung berdasarkan persamaan sebagai berikut:

$$
\begin{aligned}
\text { Sintasan }(\%)= & \text { (jumlah ikan yang hidup } \\
& \text { pada akhir penelitian/jumlah ikan } \\
& \text { saat tebar) } \times 100 \% \\
= & \left\{(\text { Wt } / \text { Wo })^{1 / t}-1\right\} \times 100(\text { NRC, 1983), } \\
& \text { dengan Wt: bobot ikan pada akhir } \\
& \text { penelitian }(\mathrm{g}) ; \text { Wo: bobot ikan pada } \\
& \text { awal penelitian }(\mathrm{g})
\end{aligned}
$$

\begin{tabular}{|c|c|c|c|c|c|c|}
\hline \multirow{2}{*}{ Bahan baku (Ingredients) } & \multicolumn{6}{|c|}{ Level Protein (Protein Levels) (\%) } \\
\hline & 30 & 35 & 40 & 45 & 50 & 55 \\
\hline Tepung ikan lokal (Local fish meal) & 34.9 & 46.9 & 55.9 & 66.9 & 76.9 & 87.9 \\
\hline Tepung kedelai (Soybean meal) & 18 & 14 & 12 & 10 & 8 & 5 \\
\hline Tepung terigu (Wheat flour) & 11 & 10 & 9 & 6 & 4 & 2 \\
\hline Dedak halus (Rice bran) & 14 & 10 & 8 & 6 & 3 & 0 \\
\hline Minyak ikan (Fish oil) & 10 & 8 & 6 & 4 & 2 & 1 \\
\hline Minyak cumi (Squid oil) & 8 & 7 & 5 & 3 & 2 & 0 \\
\hline Mineral (Mineral mix) ${ }^{1}$ & 1 & 1 & 1 & 1 & 1 & 1 \\
\hline Vitamin (Vitamin mix) ${ }^{2}$ & 3 & 3 & 3 & 3 & 3 & 3 \\
\hline Ascorbic acid & 0.1 & 0.1 & 0.1 & 0.1 & 0.1 & 0.1 \\
\hline Total & 100 & 100 & 100 & 100 & 100 & 100 \\
\hline
\end{tabular}

Tabel 1. Komposisi pakan percobaan

Table 1. Ingredient composition (\%) of experimental diets

Note: 1) Mineral mix contents (g/kg of mix): calcium 32.5\%; phosphor 10\%; Fe 6g; Mn 4g; lodine $0.075 \mathrm{~g} ; \mathrm{Cu} 0.3 \mathrm{~g} ; \mathrm{Zn}$ $3,75 \mathrm{~g}$; vit. B12 0,5 mg; vit.D $350.000 \mathrm{IU}$

2) Vitamin mix contents ( $\mathrm{g} / \mathrm{kg}$ of mix): vit. A 60,000,000 IU; vit. D3 12,000,000 IU; vit. E 120,000 mg; vit. K3 12,500 mg; vit. B1 10,000 mg; vit. B2 225,000 mg; vit. B6 10,000 mg; vit.B12 $100 \mathrm{mg}$; vit. C 150,000 mg; folic acid 5,000 mg; nicotinic acid $60,000 \mathrm{mg}$; D-pantothenic acid 50,000 mg; D1-methionine 50,000 $\mathrm{mg}$; biotin $125 \mathrm{mg}$

pakan dalam menyusun formulasi, juga terhadap pakan hasil formulasi (Tabel 2). Pakan dibuat dalam bentuk pelet kering. Kandungan asam amino pakan percobaan disajikan pada Lampiran 1.

Ikan uji diperoleh dari hasil pembenihan di Balai Besar Riset Perikanan Budidaya Laut Gondol, kemudian dipelihara dalam keramba jaring apung selama tiga minggu, bertujuan untuk adaptasi terhadap pakan uji dan lingkungan percobaan. Padat penebaran ikan uji adalah 15 ekor/keramba, dengan bobot rataan individu 17,34 $\pm 2,10$ g/ekor. Frekuensi pemberian pakan dua kali sehari pada pukul 07.00 dan 16.00 WIB secara satiasi. Pemeliharaan berlangsung selama 60 hari.

\section{RKP \\ REP \\ $\mathrm{KPH}$
= Jumlah pakan yang diberikan/ pertambahan bobot ikan
= g pertambahan bobot ikan/g pro- tein kasar pakan yang dikonsumsi (Watanabe, 1988)
$=[$ pakan yang dikonsumsi $(\mathrm{g}) /\{(\mathrm{W}$ o+ Wt)/2\} $\times$ lama pemeliharaan] $\times 100$ (Watanabe, 1988)

Analisis proksimat pakan, meliputi protein kasar (Mikro Kjeldahl), lemak kasar (Ekstraksi Soxhlet), karbohidrat (Spectrofotometer), serat kasar (Fibretex), kadar abu (Muffle), dan kalori (Bom calorimeter). Selain itu dilakukan pengamatan peubah kualitas air yang meliputi suhu air, oksigen terlarut, dan salinitas setiap hari masing-masing dengan menggunakan DO-meter, 
Tabel 2. Komposisi proksimat (\%) pakan percobaan

Table 2. Proksimat composition (\%) of experimental diets

\begin{tabular}{lrrrrrr}
\hline \multirow{2}{*}{$\begin{array}{c}\text { Komposisi nutriea } \\
\text { Nutrient composition (\%) }\end{array}$} & \multicolumn{1}{c}{ Level Protein (Protein Levels) (\%) } \\
\cline { 2 - 7 } \multicolumn{1}{c}{} & \multicolumn{1}{c}{$\mathbf{3 5}$} & \multicolumn{1}{c}{$\mathbf{4 0}$} & \multicolumn{1}{c}{$\mathbf{4 5}$} & \multicolumn{1}{c}{$\mathbf{5 0}$} & $\mathbf{5 5}$ \\
\hline Protein kasar (Crude protein) & 31.99 & 36.62 & 41.39 & 46.53 & 49.51 & 55.43 \\
Lemak kasar (Crude lipid) & 21.60 & 20.00 & 16.58 & 12.28 & 10.17 & 6.99 \\
Glukosa (Glucosa) & 1.75 & 1.60 & 1.71 & 1.58 & 1.39 & 1.35 \\
Serat kasar (Crude fibre) & 2.25 & 1.80 & 1.41 & 1.44 & 0.87 & 0.46 \\
Kadar abu. (Ash) & 12.37 & 14.61 & 16.16 & 18.45 & 19.46 & 21.46 \\
Kadar air (Moisture) & 9.30 & 9.45 & 9.2 & 9.65 & 12.60 & 12.87 \\
Nitrogen Free Extract (NFE) & 20.74 & 15.92 & 13.55 & 10.07 & 6.00 & 1.44 \\
Energi (Energy) (kcal/g) & 5.49 & 5.13 & 5.03 & 5.02 & 5.00 & 4.87 \\
\hline
\end{tabular}

dan refraktometer. Parameter tersebut digunakan sebagai data dukung untuk mengetahui kelayakan habitat. Gambaran kuantitatif data biologi ikan kerapu bebek ditampilkan secara tabulasi. Analisis keragaman dengan alat bantu paket program statistik Ver. 3 untuk menentukan pengaruh perlakuan. Kelayakan habitat dianalisis secara deskriptif.

\section{HASIL DAN BAHASAN}

Selama 60 hari pemeliharaan, pertambahan bobot ikan kerapu bebek mencapai antara $73,9 \%-124,0 \%$ tein $30 \%$. Laju pertumbuhan harian (LPH) berkisar $0,92 \%-1,35 \% /$ hari dan LPH tertinggi diperoleh pada pemberian pakan berprotein $45 \%$ sedangkan yang terendah pada perlakuan pakan berprotein $30 \%$. Semakin tinggi kadar protein dalam pakan akan memberikan keragaan pertumbuhan ikan kerapu bebek semakin baik, namun peningkatan melebihi kadar tertentu justru memberikan respon yang berlawanan. Hal ini tampak pada pertambahan bobot ikan yang semakin meningkat seiring dengan peningkatan kadar protein pakan, namun pada pakan

Tabel 3. Respons biologi ikan kerapu bebek, C. altivelis yang diberi pakan dengan kandungan protein berbeda Table 3. Biological response of humpback grouper, C. altivelis to varying dietary protein levels

\begin{tabular}{|c|c|c|c|c|c|c|}
\hline \multirow{2}{*}{ Peubah (Variables) } & \multicolumn{6}{|c|}{ Level protein (protein levels) (\%) } \\
\hline & 30 & 35 & 40 & 45 & 50 & 55 \\
\hline Bobot awal (Initial weight) (g) & 14.2 & 15.8 & 16.9 & 17.5 & 19.3 & 20.2 \\
\hline Bobot akhir (Final weight) (g) & 24.8 & 32.5 & 35.4 & 39.3 & 39.8 & 40.6 \\
\hline Pertambahan bobot (Weight gain) (\%) & 73.9 & 105.7 & 109.5 & 124.0 & 106.2 & 101.0 \\
\hline Sintasan (Sunival rate) (\%) & $97.8^{a}$ & $95.6^{\mathrm{a}}$ & $97.8^{a}$ & $95.6^{\mathrm{a}}$ & $95.6^{a}$ & $100.0^{\mathrm{a}}$ \\
\hline $\begin{array}{l}\text { Laju pertumbuhan harian } \\
\text { Daily growth rate }(\% / d)\end{array}$ & $0.92^{a}$ & $1.21^{b}$ & $1.23^{b}$ & $1.35^{b}$ & $1.22^{b}$ & $1.16^{a}$ \\
\hline $\begin{array}{l}\text { Rasio konversi pakan } \\
\text { Food convertion ratio }\end{array}$ & $2.37^{a}$ & $1.87^{b}$ & $1.69^{b}$ & $1.53^{b}$ & $1.63^{b}$ & $1.73^{b}$ \\
\hline $\begin{array}{l}\text { Konsumsi pakan harian } \\
\text { Daily food consumption ( } \% \text { bw/d) }\end{array}$ & $2.14^{a}$ & $2.10^{2}$ & $1.97^{a}$ & $1.91^{a}$ & $1.85^{\mathrm{a}}$ & $1.91^{a}$ \\
\hline $\begin{array}{l}\text { Rasio efensi protein } \\
\text { Protein efficiency ratio }\end{array}$ & $1.32^{\mathrm{a}}$ & $1.46^{b}$ & $1.42^{b}$ & $1.40^{\mathrm{b}}$ & $1.24^{a}$ & $1.04^{\circ}$ \\
\hline
\end{tabular}

Figures in the same row having the different superscript are significantly different $P<0,05$

(Tabel 3). Pertambahan bobot ikan kerapu bebek cenderung meningkat pada perlakuan protein pakan $30 \%$ sampai $45 \%$ kemudian menurun pada protein pakan 50\% - 55\%. Perlakuan pakan D (protein 45\%) memberikan respon pertumbuhan yang paling baik di antara perlakuan yang dicobakan dengan pertambahan bobot $124 \%$, sedangkan pertambahan bobot yang terendah terjadi pada perlakuan pakan berkadar pro- dengan kandungan protein $50 \%$, pertambahan bobot ikan cenderung mulai menurun, diduga karena kebutuhan protein pakan telah melampaui kebutuhan optimal. Berdasarkan analisis kovarian, laju pertumbuhan harian ikan kerapu bebek tidak menunjukkan perbedaan yang nyata $(P>0,05)$ antar perlakuan pakan dengan kandungan protein $35 \%$, $40 \%, 45 \%$, dan $50 \%$ namun kelima perlakuan tersebut 
berbeda nyata $(P<0,05)$ dengan perlakuan pakan yang kandungan proteinnya $30 \%$ dan $55 \%$.

Pakan berkadar protein $30 \%$ diduga belum mampu memenuhi kebutuhan protein bagi ikan kerapu bebek. Hasil analisis proksimat karkas ikan kerapu bebek menunjukkan kandungan protein dan lemaknya adalah 58 dan 8,12 (\% bobot kering). Menurut Giri et al. (1999), kebutuhan protein untuk pertumbuhan berbagai jenis ikan kerapu relatif tinggi, yakni 47,8\% - 60,0\% dalam pakan. Protein pakan ikan kerapu $E$. salmoides berkisar 40\% - 50\% (Chua \& Teng, 1980), E. malabaricus $47,8 \%$ (Chen \& Tsai, 1994), dan yuwana ikan kerapu bebek $C$. altivelis berbobot $5,5 \pm$ $0,1 \mathrm{~g} / \mathrm{ekor}$ adalah 54,2\% (Giri et al., 1999). Nilai ini lebih tinggi dibandingkan dengan kebutuhan protein untuk ikan ekor kuning (Seriola quinqueradiata) sebesar 43,1\% (Ruchimat et al., 1997). Boonyaratpalin (1997) melaporkan bahwa pada umumnya kebutuhan protein pakan untuk ikan kerapu cukup tinggi, akan tetapi diduga kandungan protein $40 \%$ yang didasarkan atas formulasi pakan dinilai cukup ekonomis

Berdasarkan analisis broken-line (Zeitoun et al., 1976) untuk data laju pertumbuhan harian, maka kebutuhan protein harian optimum untuk pertumbuhan maksimum ikan kerapu bebek berukuran 25-40 g/ekor adalah $45,3 \%$. Apabila hasil yang diperoleh pada penelitian ini dibandingkan dengan hasil penelitian Giri et al. (1999) terlihat bahwa kebutuhan protein untuk spesies ikan yang sama tergantung pada stadia atau bobot ikan. Ikan kerapu bebek berbobot 5,5 g ternyata membutuhkan protein yang lebih tinggi yaitu 54\%, sedangkan untuk kerapu bebek berbobot 25-40 g kebutuhan proteinnya cenderung menurun sampai $45 \%$ sesuai dengan hasil yang diperoleh pada penelitian ini. Menurut Hajen et al. (1993), faktor yang mempengaruhi tingkat kebutuhan protein pakan adalah jenis ikan, ukuran individu, dan nilai kecernaan pakan serta jenis bahan baku sumber protein (Chen \& Tsai, 1993; Giri et al., 1999).

Pakan dengan kandungan protein $45 \%$ menghasilkan rasio konversi pakan (RKP) yang terbaik sebesar 1,53 (Tabel 3) dan tidak berbeda nyata $(\mathrm{P}>0,05)$ dengan pakan berkadar protein $35 \%, 40 \%$, $45 \%, 50 \%$, dan $55 \%$, namun kelima perlakuan pakan tersebut berbeda nyata $(P<0,05)$ dengan pakan berprotein $30 \%$. Pada tingkat protein yang sama, Williams et al. (1997) melaporkan RKP untuk ikan kakap putih sebesar 1,31. Berdasarkan analisis broken-line untuk data rasio kónversi pakan dan keefisienan, pakan maka kebutuhan protein harian optimum untuk pertumbuhan maksimum ikan kerapu bebek berukuran 25 - $40 \mathrm{~g}$, masing-masing adalah $45,38 \%$ dan $45,79 \%$.
Nilai rasio efisiensi protein berkisar antara 1,04 1,46 (Tabel 3). REP tertinggi terjadi pada ikan yang diberi pakan berkadar protein 35\%. Secara umum peningkatan kandungan protein pakan diikuti dengan menurunnya nilai REP. Hal ini terjadi pada beberapa spesies ikan lain seperti ikan carp (Ogino \& Saito, 1970; Jauncey, 1982), tilapia (Mazid et al., 1979), dan juvenil snake head, Channa micropeltes (Wee \& Tacon, 1982), dan ikan kerapu malabar (Chen \& Tsai, 1993).

Kualitas air selama penelitian memperlihatkan nilai yang relatif sama untuk semua perlakuan, yaitu salinitas antara 30 - $34 \mathrm{ppt}$; suhu air $21,5^{\circ} \mathrm{C}-31,2^{\circ} \mathrm{C}$; dan oksigen terlarut 2,7 - 7,3 mg/L (Tabel 4) baik untuk pengamatan pagi (06.00 WIB) maupun sore hari (16.00 WIB). Nilai besaran peubah kualitas air masih berada pada kisaran yang layak bagi kehidupan dan pertumbuhan ikan laut pada umumnya

\section{KESIMPULAN}

Berdasarkan analisis broken-line kebutuhan protein optimal bagi pembesaran ikan kerapu bebek berbobot antara 25 - 40 g/ekor dalam keramba jaring apung adalah 45,3\% dan memberikan keragaan biologi terhadap laju pertumbuhan harian 1,35\%/hari; rasio konversi pakan 1,53 ; konsumsi pakan harian $1,91 \%$ bobot badan/hari; dan rasio efisiensi protein 1,40 lebih baik dibandingkan dengan perlakuan lainnya

\section{DAFTAR PUSTAKA}

Ahmad, T., Ardiansyah, M., dan Ismunandar, D. 1992. Pengaruh pemberian pakan berkadar protein berbeda terhadap pertumbuhan kerapu lumpur, Epinephelus tauvina. J. Penelitian Budidaya Pantai $8(2): 71-80$

Alava, V.R. and Lim, C. 1983. The quantitative dietary protein requirements of Peneus monodon juveniles in a controlled environment. Aquaculture, 30:53-61.

Boonyaratpalin, M. 1991. Nutritional studies on sea bass (Lates calcarifer). In S.S. DeSilva (ed.). Fish Nutrition Research in Asia. Proceeding of the Fourth Asian Fish Nutrition Workshop Asian Fish Soc. Spec.Publ. 5. Asian Fisheries Society, Manila. p:33-42.

Boonyaratpalin, M. 1997. Nutrient requirements of marine food fish cultured in South Asia. Aquaculture, 151:283-313.

Chen, H.Y. and Tsai, J.C. 1993. Optimal dietary protein level for the growth of juvenile grouper, Epinephelus malabaricus, fed semipurified diets. Aquaculture, 119:265-271

Chua, T.E. and Teng, S.K. 1980. Economic production of estuary grouper, Epinephelus salmoides Maxwell, reared in floating net cages. Aquaculture, 20:187228 
Tabel 4. Peubah kualitas air selama penelitian

Table 4. Water quality parameters during the experiment

\begin{tabular}{|c|c|c|c|c|}
\hline $\begin{array}{l}\text { Perlakuan } \\
\text { Treatments }\end{array}$ & $\begin{array}{l}\text { Waktu } \\
\text { Time }\end{array}$ & $\begin{array}{c}\text { Temperatur } \\
\text { Temperature }\left({ }^{\circ} \mathrm{C}\right)\end{array}$ & $\begin{array}{c}\text { Oksigen terlarut } \\
\text { Dissolved oxigen (mg/L) }\end{array}$ & $\begin{array}{c}\text { Salinitas } \\
\text { Salinity (ppt) }\end{array}$ \\
\hline $\begin{array}{l}\text { Protein } \\
(30 \%)\end{array}$ & $\begin{array}{l}06.00 \\
16.00\end{array}$ & $\begin{array}{c}21.7-29.8 \\
(26.5 \pm 2.16) \\
22.8-31.7 \\
(27.5 \pm 2.3)\end{array}$ & $\begin{array}{c}3.1-7.2 \\
(4.6 \pm 0.9) \\
3.8-7.3 \\
(5.8 \pm 1.0) \\
\end{array}$ & $\begin{array}{c}30-34 \\
(32.6 \pm 1.42) \\
30-34 \\
(32.6 \pm 1.40)\end{array}$ \\
\hline $\begin{array}{l}\text { Protein } \\
(35 \%)\end{array}$ & $\begin{array}{l}06.00 \\
16.00\end{array}$ & $\begin{array}{c}22.7-29.8 \\
(26.6 \pm 2.0) \\
23.4-31.1 \\
(27.6 \pm 2.1)\end{array}$ & $\begin{array}{c}3.2-6.9 \\
(4.7 \pm 0.8) \\
3.8-7.3 \\
(5.7 \pm 1.0) \\
\end{array}$ & $\begin{array}{c}30-34 \\
(32.6 \pm 1.42) \\
30-34 \\
(32.6 \pm 1.40)\end{array}$ \\
\hline $\begin{array}{l}\text { Protein } \\
(40 \%)\end{array}$ & $\begin{array}{l}06.00 \\
16.00\end{array}$ & $\begin{array}{c}22.6-29.8 \\
(26.6 \pm 2.1) \\
23.2-31.2 \\
(27.6 \pm 2.1) \\
\end{array}$ & $\begin{array}{c}3.1-7.3 \\
(4.7 \pm 0.9) \\
3.8-7.1 \\
(5.7 \pm 1.3) \\
\end{array}$ & $\begin{array}{c}30-34 \\
(32.6 \pm 1.42) \\
30-34 \\
(32.6 \pm 1.40)\end{array}$ \\
\hline $\begin{array}{l}\text { Protein } \\
(45 \%)\end{array}$ & $\begin{array}{l}06.00 \\
16.00\end{array}$ & $\begin{array}{c}21.5-29.8 \\
(26.6 \pm 2.2) \\
23.0-31.2 \\
(27.6 \pm 2.1) \\
\end{array}$ & $\begin{array}{c}2.7-7.1 \\
(4.6 \pm 0.8) \\
3.8-7.1 \\
(5.7 \pm 1.0) \\
\end{array}$ & $\begin{array}{c}30-34 \\
(32.6 \pm 1.42) \\
30-34 \\
(32.6 \pm 1.40)\end{array}$ \\
\hline $\begin{array}{l}\text { Protein } \\
(50 \%)\end{array}$ & $\begin{array}{l}06.00 \\
16.00\end{array}$ & $\begin{array}{l}21.6-29.8 \\
(26.5 \pm 2.2) \\
23.2-31.1 \\
(27.6 \pm 2.1) \\
\end{array}$ & $\begin{array}{c}3.2-7.1 \\
(4.6 \pm 0.8) \\
3.8-7.1 \\
(5.7 \pm 1.0) \\
\end{array}$ & $\begin{array}{c}30-34 \\
(32.6 \pm 1.42) \\
30-34 \\
(32.6 \pm 1.40)\end{array}$ \\
\hline $\begin{array}{l}\text { Protein } \\
(55 \%)\end{array}$ & $\begin{array}{l}06.00 \\
16.00\end{array}$ & $\begin{array}{l}22.3-29.8 \\
(26.6 \pm 2.1) \\
23.0-31.2 \\
(27.6 \pm 2.2)\end{array}$ & $\begin{array}{c}3.0-7.4 \\
(4.7 \pm 0.9) \\
3.8-6.9 \\
(5.7 \pm 1.0)\end{array}$ & $\begin{array}{c}30-34 \\
(32.6 \pm 1.42) \\
30-34 \\
(32.6 \pm 1.40)\end{array}$ \\
\hline
\end{tabular}

Note: (mean \pm SD)

Giri, N.A., Suwirya, K., dan Marzuki, M. 1999. Kebutuhan protein, lemak dan vitamin $C$ untuk yuwana ikan kerapu tikus (Cromileptes altivelis). J. Penelitian Perikanan Indonesia Vol.V(3):38-46

Halver, J.E. 1976. The nutritional requirement of cultivated warm water and coldwater fish species. Advance in Aquaculture. p.574-580.

Jauncey, K. 1982. The effects of varying dietary protein levels on the growth, food conversion, protein utilization and body composition of juvenile tilapias (Sarotherodon mossambicus). Aquaculture, 27:4354 .

Lovell, R.T. 1980. Practical Fish Diets. In Fish feed technology. United Nation Development Programme, Food and Agriculture Organization of United Nation, Rome. p.32-40.

Mazid, M.A. Tanaka, Y., Katayama, T., Rahman, M.A., Simpson, K.L., and Chichester, C.O., 1979. Growth response of Tilapia zillii fingerling fed isocaloric diets with variable protein levels. Aquaculture, 18:115122.
NRC. 1983. Nutrient Requirement of Warm water Fish and Shellfish. National Academy Press, Washington. $102 \mathrm{pp}$.

Ogino, C. and Saito, K. 1970. Protein nutrition in fish. I. The utilization of dietary protein by carp. Bull. Jpn. Soc. Sci. Fish., 36:250-254.

Ruchimat, T., Masumoto, T., Hosokawa, H., Itoh, Y., and Shimeno, S. 1997. Quantitative lysine requirement of yellowtail (Seriola quinqueradata). Aquaculture, 158:331-339.

Sakaras, W. 1986. Optimum stocking density of sea bass, Lates calcarifer culture in cage. Proceeding ACIAR, 20:172-175.

Watanabe, T. 1988. Fish nutrition and Mari culture. JICA Textbook The General Aquaculture Cause. Departement of Aquatic Bioscience. Tokyo University of Fisheries. 233 pp.

Wee, K.L. and Tacon, A.G.J. 1982. A preliminary study on the dietary protein requirement of juvenile snakehead. Bulletin of the Japanese Society of Sci. entific Fisheries, 48:1463-1468. 
ramundi Aquaculture Seminar, 28 Nov. 1997, Nambour.

Wong, F.J. and R. Chou. 1989. Dietary protein requirement of early grow-out seabass (Lates calcarifer) and same observation on the performance of two practical formulated feeds. Singapore Joumal of Primary
Industries. The Primary Production Development. 17(2):134 pp.

Zeitoun, I.H., Ullrey, D.E. and Magee, W.T., 1976. Quantifying nutrient requirements of fish. J. Fish. Res. Board Can. 33:167-172. 
Lampiran 1. Profil asam amino pakan percobaan ikan kerapu bebek pada level protein berbeda Annex 1. Profile amino acid of humpback grouper feed at different levels of protein

\begin{tabular}{lcccccc}
\hline \multirow{2}{*}{ Asam amino (amino acid) } & \multicolumn{6}{c}{ Diet percobaan (test diets) } \\
\cline { 2 - 7 } & A & B & C & D & E & F \\
\hline Aspartic acid & 1.58 & 1.60 & 1.77 & 2.00 & 2.28 & 2.48 \\
Glutamic acid & 2.16 & 2.44 & 2.48 & 2.99 & 93.3 & 3.53 \\
Serine & 0.59 & 0.64 & 0.36 & 0.39 & 0.53 & 0.67 \\
Histidine & 0.33 & 0.35 & 0.36 & 0.39 & 0.53 & 0.67 \\
Glicyne & 0.83 & 0.97 & 1.27 & 1.34 & 1.42 & 1.64 \\
Threonine & 0.55 & 0.63 & 0.71 & 0.71 & 0.92 & 1.02 \\
Arginine & 0.82 & 0.91 & 1.06 & 1.15 & 1.23 & 1.46 \\
Alanine & 0.82 & 0.96 & 1.18 & 1.25 & 1.40 & 1.77 \\
Tyrosine & 0.44 & 0.54 & 0.66 & 0.94 & 0.81 & 0.95 \\
Methionine & 0.38 & 0.45 & 0.62 & 0.73 & 0.64 & 0.67 \\
Valine & 0.76 & 0.87 & 0.97 & 1.12 & 1.27 & 1.22 \\
Phenylalanine & 0.57 & 0.64 & 0.70 & 0.77 & 0.88 & 0.95 \\
Isoleucine & 0.64 & 0.73 & 0.89 & 1.02 & 1.18 & 1.18 \\
Leucine & 0.81 & 0.89 & 1.09 & 1.12 & 1.44 & 1.46 \\
Lysine & 0.17 & 0.17 & 0.97 & 1.46 & 1.22 & 3.71 \\
\hline Total Asam amino (amino acid) & $\mathbf{1 1 . 4 5}$ & $\mathbf{1 2 . 7 7}$ & $\mathbf{1 5 . 4 4}$ & $\mathbf{1 7 . 8 0}$ & $\mathbf{1 9 . 4 2}$ & $\mathbf{2 3 . 6 7}$ \\
\hline
\end{tabular}

